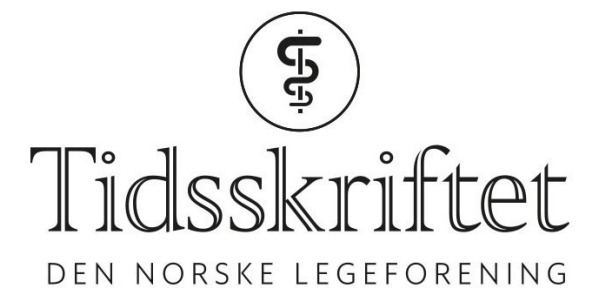

DEN NORSKE LEGEFORENING

\title{
Nyfødte barn og sårbare mødre
}

KOMMENTAR

\section{HALLVARD REIGSTAD}

E-post: hallvard.reigstad@helse-bergen.no

Hallvard Reigstad er seksjonsoverlege.

Ingen oppgitte interessekonflikter.

Malin Eberhard-Gran, professor ved Universitetet i Oslo, advarer mot tidleg heimreise etter fødsel (1). Helse Bergen/Haukeland universitetssjukehus blir brukt som sannhetsvitne på at dette vil gå galt. Ho drar parallellar til USA i 1950-åra med uoppdaga alvorleg gulsott ved tidleg heimreise. Det er laga nasjonale retningsliner for barn som skal følgjast spesielt nøye med tanke på tidleg gulsott. Vi følgjer desse, også på barn som reiser tidleg heim etter fødsel.

Det blir også referert til ein studie frå Bergen med barn med alvorleg vekttap og hypernatremi (2). Viktigaste lærdommen, omtalt i referanselista i studien, er at også erfarent helsepersonell vanskeleg kan bedømme hydrering og vektutvikling hos nyfødde uten å bruke vekt. Derfor innførte vi rutinemessig vekt av nyfødde på dag tre. Etter dette har vi ikkje sett tilfelle med alvorleg vekttap og hypernatremi.

Det blir anført at barnelegar fryktar at kortare liggetid kan medføre at ein overser sjeldne, men alvorlege tilstandar med debut første dagane etter fødsel, som sepsis, hjertefeil og metabolske sjukdomar. Alle nyfødde blir undersøkt med pulsoksimetri før utreise, saman med god prenatal undersøkelse har dette høg sensitivitet med tanke på å oppdage hjertefeil. Det er såpass stort fødselstal ved Haukeland universitetssjukehus at vi årleg har fleire barn med tidleg sepsis. Med kortare liggetid har vi imidlertid ikkje opplevt at barn som er heimskrevne har fått forsinka behandling. Medfødde stoffskiftesjukdomar som debuterer i løpet av første leveveke er sjeldne, men vi har høg beredskap for å finne og behandle desse, og vi meiner å ha ei så god kontaktordning med utskrevne familiar at diagnostikk ikkje skal bli forsinka.

Svangerskaps- og barseldepresjon er nevnt som spesiell problemstilling. Dette er ein svært alvorleg tilstand og viktig å oppdage. Mange av desse debuterer i svangerskapet, nokre få dei første dagane etter fødsel, mange dei første månadene etter fødselen (3).Ved utvida liggetid frå fire timar til fem døgn vil ein sannsynlegvis finne svært få av desse.

Tidleg heimreise betyr ikkje at nybakte foreldre blir overlatt til seg sjølv. Vi har god erfaring med daglege besøk av jordmor, og det er enkel kommunikasjonsveg til fødeavdelinga og til barnelegar dersom foreldre eller jordmødre er bekymra. Mange foreldre etterspør tidleg heimreise, og dei aller fleste er godt fornøgde med dette, så lenge dei får god oppfølging.

Ikkje alle skal tidleg heim: Nokre mødre er for sjuke eller har for vanskelege sosiale forhold, nokre barn er for umodne eller for små. Men ved å spisse behandlinga mot dei som treng 
det, kan vi gi eit betre tilbod til riktige mødre og barn.

LITTERATUR:

1. Eberhard-Gran M. Nyfødte barn og sårbare mødre. Tidsskr Nor Legeforen 2018; 138. doi: 10.4045/tidsskr.18.0878. [PubMed][CrossRef]

2. Tjora E, Karlsen LC, Moster D et al. Early severe weight loss in newborns after discharge from regular nurseries. Acta Paediatr 2010; 99: 654-7. [PubMed][CrossRef]

3. Viguera A. Uptodate.com. Postpartum unipolar major depression: Epidemiology, clinical features, assessment, and diagnosis.

https://www.uptodate.com/contents/postpartum-unipolar-major-depression-epidemiology-clinical-fe atures-assessment-and-diagnosis?searchperinatal\%2odepression\%2oprevalence\&sourcesearch_result\&selectedTitle=1 140\&usage_typedefault\&display_rank=1(28.12.2018).

Publisert: 28. januar 2019. Tidsskr Nor Legeforen. DOI: 10.4045/tidsskr.19.0018

(C) Tidsskrift for Den norske legeforening 2020. Lastet ned fra tidsskriftet.no 